\title{
GENOTYPIC EFFECTS, OXIDATIVE STRESS AND TOLERANCE MECHANISMS INDUCED BY CADMIUM IN TWO Lactuca sativa CULTIVARS. \\ El-Kafafi. E. ${ }^{a, \star} ;$ Fatma M. El-Demerdash ${ }^{b} ;$ M. El-Sheikh ${ }^{a}$ and
} A. A. Helaly ${ }^{c}$

a Botany Dept., Fac. Agric., Al-Azhar University, Nasr City, Cairo, Egypt., b Department of Environmental Studies, Institute of Graduate Studies and Research, Alexandria University, Alexandria, Egypt

${ }^{c}$ Horticulture Dept., Fac. Agric., Al-Azhar Univ., Nasr City, Cairo, Egypt.

* Address correspondence to Dr. El-Sayed El-Kafafi, Botany Department, Faculty of Agriculture, Al-Azhar University, Nasr City, Cairo, Egypt., Email: sayedelkafafi@gmail.com

\begin{abstract}
A hydroponic experiment was carried out to investigate the effect of cadmium (Cd) on differential expression, oxidative stress and some antioxidant enzyme activities in two Lactuca sativa cultivars (Balady, related Romaine Group and Great leaks, related Crisp Group). Cd phytotoxicity was shown by growth retardation of Balady and Great leaks. Results showed that Great leaks showed more sensitivity to $\mathrm{Cd}$ toxicity than Balady cultivar. Increasing $\mathrm{Cd}$ supply markedly reduced the total chlorophyll, dry matter of both Lactuca cultivars and these decreases were more marked in great leaks. Increased $\mathrm{Cd}$ accumulation in various plant parts in both the Lactuca cultivars was observed as $\mathrm{Cd}$ concentration increased. Cd accumulated in the roots was much higher than in the shoot in the two cultivars, but more observed in the case of Balady cultivar. Balady cultivar had less uptake of $\mathrm{Cd}$ by shoot about two times than Great leaks shoot cultivar indicating that there are co-ordination of gene expression, regulation ion transport process operating in different root layer more efficient in Balady cultivar compared with Great leaks. Moreover, the induction of expression and activities of antioxidant enzymes and non protein thiol (NPT) increased in Balady cultivar more than Great leaks leading to $\mathrm{H}_{2} \mathrm{O}_{2}$ burst, lipid peroxidation, and growth inhibition. These gene expression and activities of antioxidant enzymes confer Balady cultivar some measure of $\mathrm{Cd}$ tolerance and presence of strong Cd-binding proteins in the roots. In conclusion, these results may be regarded as an indication of better tolerance mechanism of Balady cultivarmore
\end{abstract} than that of Great leaks to Cd contamination.

Keywords: Lactuca sativa, Cadmium Toxicity, Oxidative Stress, Biomarkers, Phytotoxicity.

\section{INTRODUCTION}

Contamination of soil and water by toxic heavy metals constitutes a major environmental hazard to human health. Cadmium (Cd), classified as a human carcinogen (Waisberg et al., 2003), is released into the environment by anthropogenic activities such as mining, smelting, fuel composition, disposal of industrial effluents and sewage sludge as well as application of phosphate fertilizers (Clemens, 2006). It is a non-essential metal for the plants and humans, enters crops through roots, accumulates in plants and affects human health (Wagner, 1993). Plants exposed to Cd showed 
reductions in photosynthesis, water and nutrient uptake (Sanità di Toppi and Gabbrielli, 1999). As a consequence, Cd-exposed plants showed various symptoms of injury such as chlorosis, accompanied by a lowering of photosynthetic rate growth inhibition, browning of root tips (Das et al., 1997), disturbs cell proliferation (Rosas et al., 1984), impedes respiration (Lee et al., 1976), reduces mitochondrial electron transport (Miller et al., 1973), induces high vacuolization in cytoplasm and nuclei, and increases disintegration of organelles (Liu and Kottke, 2003). With increased Cd dose in nutrient culture up to $10 \mathrm{mg} \mathrm{L}^{-1}$ causes yield reduction at $75 \%$ for bean, $65 \%$ for sugar beet, $60 \%$ for turnip and $40 \%$ for corn (Haktanır and Arcak, 1978). Tolerance indexes of tomato and corn plants changed in the range of 79.2-7.8 and 68.618 in response to $\left(0.05-20 \mu \mathrm{g} \mathrm{mL}^{-1} \mathrm{Cd}\right)$, respectively (Yildiz, 2005). Cd toxicity has been found to interfere with electron transport chains or block antioxidant enzymes structures, leading to accumulation of $\mathrm{H}_{2} \mathrm{O}_{2}$, and oxidative damage, membrane leakage and finally cell death (Schutzendubel et al., 2002). Accumulation of $\mathrm{Cd}$ in plant cell generally results in functional alteration of the physiological pathways (Sanità di Toppi and Gabbrielli, 1999).

Approximately percent of the water that a plant absorbs from the soil is by evaporation from the leaves. Most transpiration occurs through the stomata, the numerous stomatal pores that are so effective in gas exchange for the photosynthesis also provide opening through which water vapor escapes living minerals required for the plant growth (Haktanir and Arcak, 1978). Harmful effects produced by $\mathrm{Cd}$ might be explained by its ability to inactivate enzymes possibly through reaction with the $\mathrm{SH}$-groups of proteins (Fuhrer, 1982). In other words, toxicity of Cd may result from its binding to sulfydryl groups of proteins leading to inhibition of activity or disruption of structure, disturbance of cellular redox control (Schutzendubel et al., 2002), and/or inducing the production of reactive oxygen species (Romero-Puertas et al., 2004). Therefore, the present study aimed to evaluating the impact of different $\mathrm{Cd}$ concentration on lipid peroxidation and activity of some antioxidant enzymes, some nutrients uptake, cytotoxicity, phytotoxicity in addition to accumulation rate in Lactuca sativa cultivars. For this purpose, it is important to understand the mechanisms of $\mathrm{Cd}$ toxicity and tolerance mechanism in plants.

\section{MATERIALS AND METHODS}

\section{Plant materials and experimental design}

Hydroponic experiment was used to study phytotoxicity oxidative stress and differential expression and activities of antioxidant enzyme and concentration of cadmium (Cd) in different plant parts in two Lactuca sativa cultivar (Balady related Romaine Group and Great leaks, related Crisp Group). The experiment was carried out at the Faculty of Agriculture, AlAzhar University, Cairo, Egypt during two seasons. The two Lactuca sativa cultivar were germinated in sand culture for 2 weeks. Then the plants were transferred to containers (7 liters per pot) having nutrient solution (stable water culture technique). The plants grown in Murashige and Skoog basal medium nutrient solution modified (containing: 1/4 MS) was used as growth 
medium. After one week in the standard nutrient solution and adjusted $\mathrm{pH}$ to 6.0 . The nutrient solution was renewed twice a week and aerated continuously. The pots were randomly arranged several times during the growth period. Plants were grown under controlled climatic conditions and subjected to increasing $\mathrm{Cd}$ supply in the form of $\mathrm{CdCl}_{2}(0,16,24$, and 32 $\mu \mathrm{mol} / \mathrm{l})$. After 10 days of treatment, the plants were harvested, washed twice with distilled water and divided into shoots and roots, then representative portions were taken for wet digested using a mixture of $\mathrm{HClO}_{4}$ and $\mathrm{H}_{2} \mathrm{SO}_{4}$ at a rate of 1:1 to detriment some nutrients composition ( $\mathrm{Ca}, \mathrm{Fe}, \mathrm{Mn}, \mathrm{Zn}$ and $\mathrm{Cd}$ ) by Inductively Coupled Plasma Spectrometer (ICP) plasma 400 (Page et al., 1982).

\section{Chlorophyll Content}

Total chlorophyll was estimated according to the spectrophotometric method described by Hipkins and Baker (1986). Approximately $50 \mathrm{mg}$ (fresh mass) of leaves was placed in $3 \mathrm{~mL}$ of $100 \%$ methanol in $5 \mathrm{~mL}$ vials. The vials were covered and incubated at $23^{\circ} \mathrm{C}$ for $2 \mathrm{~h}$ in darkness. Each sample was mixed, the methanol fraction decanted, and the absorbance measured at 650 and $665 \mathrm{~nm}$.

\section{Tolerance indexes}

The $\mathrm{Cd}$ tolerance indexes were measured according to the following equation of Das et al., 1999.

$$
\text { Tolerance indexes }=\frac{\text { Growth (dry matter) increase in Cd level }}{\text { Growth (dry matter) in nutrient solution without Cd }} \times 100
$$

Tissue preparation for enzymatic antioxidants in Balady and Great leaks roots and shoot:-

Fresh root or shoot samples $(0.5 \mathrm{~g})$ were ground in liquid $\mathrm{N}_{2}$ and homogenized in an ice-bath in $10 \mathrm{~mL}$ homogenizing solution containing 50 $\mathrm{mM}$ potassium phosphate buffer and $1 \%(\mathrm{w} / \mathrm{v})$ polyvinylpyrrolidone $(\mathrm{pH} 7.8)$. The homogenate was centrifuged at $8000 \mathrm{xg}$ at $4{ }^{\circ} \mathrm{C}$ for $15 \mathrm{~min}$ and the resulting supernatant was used for enzyme assays.

\section{Glutathione S-transferase (GST) determination in balady and great leaks roots and shoots}

Glutathione S-transferase (GST, 2.5.1.18) activity was assayed according to Habig and Jacoby (1981). The reaction mixture consisted of 100 $\mathrm{mM}$ potassium phosphate buffer $(\mathrm{pH}$ 6.5), $0.1 \mathrm{mM}$ 1-chloro 2,4dinitrobenzene (CDNB), $10 \mathrm{mM} \mathrm{GSH}$ and a suitable aliquot of enzyme extract. The CDNB conjugate formation was followed for $5 \mathrm{~min}$ at $340 \mathrm{~nm}$. Specific activity of the enzyme was calculated using the extinction coefficient, $9.6 \mathrm{mM}^{-1} \mathrm{~cm}^{-1}$ and is expressed as units $\mathrm{mg}^{-1} 1$ protein. The protein content in the supernatants was measured according to Lowry et al. (1951).

Catalase determination in Balady and Great leaks roots and shoot

Catalase (CAT, EC 1.11.1.6) activity was measured as disappearance of $\mathrm{H}_{2} \mathrm{O}_{2}$ at $240 \mathrm{~nm}$ (Cakmak and Marschner, 1992). A $2 \mathrm{ml}$ of reaction mixture consisted of $25 \mathrm{mM}$ phosphate buffer ( $\mathrm{pH} 7.0), 10 \mathrm{mM} \mathrm{H}_{2} \mathrm{O}_{2}$ and $0.2 \mathrm{ml}$ of enzyme extract. Activity was calculated using an extinction coefficient of 39.4 $\mathrm{mM}^{-1} \mathrm{~cm}^{-1}$ and expressed as enzyme unit $\mathrm{g}^{-1} \mathrm{FW}$. One CAT unit was defined as the enzyme amount that decomposes $1 \mu \mathrm{M} \mathrm{H}_{2} \mathrm{O}_{2} \min ^{-1}$. 


\section{Determination of MDA concentration in Balady and Great leaks roots} and shoot

Root or shoot tissues (500 mg) were homogenized in $3 \mathrm{~mL} 0.1 \%$ trichloroacetic acid (TCA) solution. The homogenate was centrifuged at 2500 $\mathrm{xg}$ for $10 \mathrm{~min}$ and the supernatant was assayed for malondialdehyde (MDA) concentration with thiobarbituic acid (TBA) test using the method given by Heath and Packer (1968).

Determination of Hydrogen peroxide concentration $\left(\mathrm{H}_{2} \mathrm{O}_{2}\right)$ in Balady and Great leaks roots and shoot

For determination of $\mathrm{H}_{2} \mathrm{O}_{2}$ concentration, root or shoot tissue $(100 \mathrm{mg})$ was extracted with $5 \mathrm{ml}$ TCA $(0.1 \%, \mathrm{w} / \mathrm{v})$ in an ice bath and centrifuged at $12,000 \times g$ for $15 \mathrm{~min}$ (Velikova et al., 2000). An aliquot $(0.5 \mathrm{ml}$ ) of supernatant was added to $0.5 \mathrm{ml}$ of phosphate buffer $(\mathrm{pH} 7.0)$ and $1 \mathrm{ml}$ of $1 \mathrm{M}$ potassium iodide. The absorbance of the mixture was read at $390 \mathrm{~nm} . \mathrm{H}_{2} \mathrm{O}_{2}$ content was determined using the extinction coefficient $0.28 \mu \mathrm{M}^{-1} \mathrm{~cm}^{-1}$ and amount expressed as nmol g ${ }^{-1} \mathrm{FW}$.

Determination of NPT concentration in Balady and Great leaks roots and shoots

The concentration of non-protein thiols (NPT) was determined by measuring the absorbance at $412 \mathrm{~nm}$ following the method of Metwally et al. (2003). For this, $0.5 \mathrm{~g}$ of fresh root or shoot segments were homogenized in an ice-bath in $5 \mathrm{~mL}$ of potassium phosphate buffer $(\mathrm{pH} \mathrm{8.0)}$, and the homogenate was centrifuged at $10,000 \mathrm{xg}$ for $20 \mathrm{~min}$. The supernatant was used for NPT assay using 5, 5-dithio-2, 2-dinitrobenzoic acid as a reagent.

\section{Rapid extraction of proteins}

This method is very fast and efficient for simple control of the protein profile on SDS-PAGE denaturing gel. The plant material fresh seedling ground in liquid N2 The products powder is weighed and taken up in an equal volume of $4 x$ loading buffer $(500 \mathrm{mM}$ Tris- $\mathrm{HCl} \mathrm{pH} 6.8,12 \%$ SDS (w / v) glycerol $20 \%$ (v / v) $40 \mathrm{mM}$ DTT, $20 \mathrm{mM}$ bromophenol blue) The sample is denatured for $10 \mathrm{~min}$ at $100^{\circ} \mathrm{C}$ and then centrifuged $5 \mathrm{~min}$ at maximum speed (Eppendorf centrifuge $5417 \mathrm{R}$ ). The supernatant can then be used for electrophoreses separation.

\section{Statistical analysis}

The experiments were arranged in a randomized design. Differences among Cd concentrations and cultivars, as well as interactions between these variables, were tested using the SPSS statistical program. Statistical variance analysis of the data with three replicates was performed using ANOVA and compared with least significant differences (LSD) at the $5 \%$ level.

\section{RESULTS}

Effect of Cd treatment on chlorophyll content of two lactuca g cultivars.

Effect of $\mathrm{Cd}$ concentration on the chlorophyll content during seedlings development of two lactuca cultivars after 10 days of treatments was studied was shown in Table (1). Total chlorophyll decreased nearly linearly with increasing $\mathrm{Cd}$ in nutrient solution from 16-32 $\mu \mathrm{mol} / \mathrm{l}$. In seedlings treated with 
$32 \mu \mathrm{mol} / \mathrm{L} \mathrm{Cd}$, total chlorophyll was decreased by $53.02-63.09 \%$ in Balady and Great leaks, respectively as compared with control.

Table 1: Effect of cadmium treatment on chlorophyll content of Balady and Great Leaks cultivars.

\begin{tabular}{|c|c|c|c|c|}
\hline \multirow[t]{2}{*}{ Treatment } & \multirow{2}{*}{$\begin{array}{c}\text { Balady } \\
\mu \mathrm{g} / \mathrm{g} . \mathrm{D} . W \\
\text { chlorophyll }\end{array}$} & \multirow{2}{*}{$\begin{array}{c}\text { Great leaks } \\
\mu g / g . D . W \\
\text { chlorophyll }\end{array}$} & \multicolumn{2}{|c|}{ Percentage decrease in total chlorophyll } \\
\hline & & & \% Balady & $\%$ Great leaks \\
\hline Control MS & 1094 & 997 & 100 & 100 \\
\hline $16 \mu \mathrm{mol}$ & 805 & 681 & 26.42 & 31.70 \\
\hline $24 \mu \mathrm{mol}$ & 634 & 509 & 42.05 & 48.95 \\
\hline $32 \mu \mathrm{mol}$ & 514 & 368 & 53.02 & 63.09 \\
\hline
\end{tabular}

Effect of Cd treatment on dry matter and clerance index of two lactuca cultivars.

The results showed also differential disposition in both Lactuca sativa and variable decrease with increasing $\mathrm{Cd}$ concentration as compared with control. The highest yield was obtained in control. Dry matter production decreased dramatically with increasing concentrations of $\mathrm{Cd}$ (Table 2). However, dry matter of Balady decreased to $61.79 \%$ at $32 \mu \mathrm{mol} \mathrm{Cd}$ applications and reached to $51.08 \%$ in Great leaks at the same Cd levels. The yield reduction in two cultivars, Balady and Great leaks plants with tolerance index of $73.44 \%$ and $70.88 \%$ were approximately 26.56 and $29.12 \%$ decreased in dry matter at $16 \mu \mathrm{mol} \mathrm{Cd}$, respectively. However, yield reduction of Balady and Great leaks were $38.21 \%$ and 49.92 at $32 \mu \mathrm{mol} \mathrm{Cd}$, respectively (Table 2 ).

Table 2: Effect of cadmium treatment on dry matter and tolerance index of Balady and Great leaks cultivars

\begin{tabular}{|c|c|c|c|c|}
\hline Treatment & $\begin{array}{c}\text { g/plant D.M } \\
\text { Balady }\end{array}$ & $\begin{array}{c}\text { Tolerance index } \\
\% \text { Balady }\end{array}$ & $\begin{array}{c}\text { g/plant D.M } \\
\text { Great leaks }\end{array}$ & $\begin{array}{c}\text { Tolerance index\% } \\
\text { Great leaks }\end{array}$ \\
\hline control MS & 0.351 & $100 \%$ & 0.3232 & $100 \%$ \\
\hline $16 \mu \mathrm{mol}$ & 0.2578 & $73.44 \%$ & 0.2291 & $70.88 \%$ \\
\hline $24 \mu \mathrm{mol}$ & 0.2517 & $71.70 \%$ & 0.2082 & $64.41 \%$ \\
\hline $32 \mu \mathrm{mol}$ & 0.2169 & $61.79 \%$ & 0.1651 & $51.08 \%$ \\
\hline
\end{tabular}

Effect of cadmium treatment on cadmium uptake and some nutrients content of two Lactuca cultivars.

Cd uptake and accumulation in various plant parts of both Lactuca cultivars was tested. Increased $\mathrm{Cd}$ accumulation two times in roots was observed with $\mathrm{Cd}$ application of $32 \mu \mathrm{mol} / \mathrm{l}$ in medium more than that of shoots (Tables 3 and 4). To furthet explore modifications induced by the $\mathrm{Cd}$ concentration on plants uptake of macro- and micronutrients, in the two lactuca cultivars. The level of nutrients absorbed by plants is related to the amount of available nutrients in the growth medium. Meanwhile, uptake of nutrients increased for some nutrients or decreased for the others depending on antagonistic or synergistic (interactions) effects among plant nutrients. Calcium content of the Great leaks was decreased in all Cd treatments, but it 
increased with Balady cultivar especially in root parts at treatments Cd levels. Manganese content of Balady was not stable and did not show a clear trend and the same results in Great leaks roots, but it decreased in Great leaks shoots with increase the cadmium levels. $\mathrm{Zn}$ content of Great leaks was low in all treatments, except the control but with Balady cultivar, it increased in root and shoot parts. Fe content of Great leaks cultivar was low in all treatments, except the control but with Balady cultivar, it increased especially in root parts (Tables 3 and 4 ).

Table 3: Effect of cadmium treatment on cadmium uptake and some nutrient contents of Balady cultivars.

\begin{tabular}{|c|c|c|c|c|c|}
\hline \multirow{2}{*}{$\begin{array}{c}\text { Treatments } \\
\text { mg/l }\end{array}$} & Cd & Ca & Fe & Mn & Zn \\
\cline { 2 - 6 } & Shoot Balady \\
\hline Control MS & 0.0025 & 9.090 & 2.549 & 0.234 & 0.714 \\
\hline $16 \mu \mathrm{mol}$ & 0.3292 & 26.755 & 6.733 & 0.254 & 1.944 \\
\hline $24 \mu \mathrm{mol}$ & 0.281 & 9.980 & 2.650 & 1.575 & 1.376 \\
\hline $32 \mu \mathrm{mol}$ & 0.377 & 11.662 & 2.917 & 0.143 & 2.973 \\
\hline LSD 0.01 & 0.076 & 3.18 & 1.89 & 0.29 & 0.71 \\
\hline \multicolumn{5}{|c|}{ Root Balady } \\
\hline control MS & 0.001 & 5.560 & 4.013 & 0.173 & 0.444 \\
\hline $16 \mu \mathrm{mol}$ & 0.556 & 25.714 & 12.841 & 0.185 & 4.495 \\
\hline $24 \mu \mathrm{mol}$ & 1.220 & 12.983 & 11.031 & 0.156 & 1.274 \\
\hline $32 \mu \mathrm{mol}$ & 1.959 & 14.288 & 9.777 & 0.173 & 2.206 \\
\hline LSD 0.01 & 0.314 & 3.46 & 2.41 & 0.13 & 0.93 \\
\hline
\end{tabular}

Table 4: Effect of cadmium treatment on cadmium uptake and some nutrient contents of Great leaks cultivars.

\begin{tabular}{|c|c|c|c|c|c|}
\hline \multirow{2}{*}{$\begin{array}{c}\text { Treatments } \\
\text { mg/l }\end{array}$} & \multicolumn{5}{|c|}{ lons mg/g dry weight } \\
\cline { 2 - 6 } & Cd & Ca & Fe & Mn & Zn \\
\hline \multicolumn{5}{|c|}{ Shoot Great leaks } \\
\hline control MS & 0.0035 & 25.366 & 4.172 & 0.333 & 6.144 \\
\hline $16 \mu \mathrm{mol}$ & 0.422 & 6.739 & 2.976 & 0.222 & 1.617 \\
\hline $24 \mu \mathrm{mol}$ & 0.539 & 13.687 & 2.729 & 0.239 & 1.505 \\
\hline $32 \mu \mathrm{mol}$ & 0.630 & 14.670 & 2.572 & 0.189 & 1.376 \\
\hline LSD 0.01 & 0.12 & 1.97 & 0.89 & 0.067 & 0.84 \\
\hline \multicolumn{7}{|c|}{ Root Great leaks } \\
\hline control MS & 0.0049 & 69.403 & 45.872 & 0.953 & 5.245 \\
\hline $16 \mu \mathrm{mol}$ & 0.888 & 12.117 & 8.892 & 0.182 & 0.930 \\
\hline $24 \mu \mathrm{mol}$ & 2.478 & 12.382 & 11.687 & 0.226 & 3.194 \\
\hline $32 \mu \mathrm{mol}$ & 1.694 & 11.591 & 7.975 & 0.162 & 0.218 \\
\hline LSD 0.01 & 0.23 & 3.25 & 2.62 & 0.28 & 1.47 \\
\hline
\end{tabular}

\section{Lipid peroxidation}

Lipid peroxidation in root and shoot tissue was determined by measuring malondialdehyde (MDA), a major thiobarbituric acid reactive species (TBARS) and product of lipid peroxidation. MDA content increased significantly $(p<0.05)$ after treatment with different concentrations of $\mathrm{Cd}$ (Table 5). The increase in MDA is more pronounced in Great leaks shoots and roots. 
Table 5: MDA concentrations of roots and shoots in Great leaks and Balady cultivars exposed to different $\mathrm{Cd}$ concentrations

\begin{tabular}{|c|c|c|c|c|}
\hline \multicolumn{5}{|c|}{ Cadmium concentrations } \\
\hline Plant cultivars & $\mathbf{0} \boldsymbol{\mu m o l}$ & $\mathbf{1 6} \boldsymbol{\mu m o l}$ & $\mathbf{2 4} \boldsymbol{\mu m o l}$ & $\mathbf{3 2} \boldsymbol{\mu m o l}$ \\
\hline \multicolumn{5}{|c|}{ Shoot MDA } \\
\hline Great leaks & $30.51 \pm 0.87$ & $36.22 \pm 0.55^{\star}$ & $38.56 \pm 1.58^{*}$ & $42.49 \pm 1.09^{*}$ \\
\hline Balady & $35.57 \pm 1.22$ & $39.69 \pm 0.96$ & $45.68 \pm 1.20^{*}$ & $49.05 \pm 1.13^{*}$ \\
\hline \multicolumn{5}{|c|}{ Root MDA } \\
\hline Great leaks & $38.44 \pm 0.73$ & $46.43 \pm 1.68^{*}$ & $53.54 \pm 1.68^{*}$ & $57.91 \pm 1.47^{*}$ \\
\hline Balady & $42.12 \pm 1.03$ & $47.36 \pm 1.01$ & $55.60 \pm 1.69^{*}$ & $60.09 \pm 1.76^{*}$ \\
\hline
\end{tabular}

Values are means \pm SEM of three different replicates.

MDA, malonaldehyde concentrations, nmole/g fresh weight

*Differences were significant at $p<0.05$.

\section{$\mathrm{H}_{2} \mathrm{O}_{2}$ amount}

Parallel to changes in MDA content, there was a significant increase in $\mathrm{H}_{2} \mathrm{O}_{2}$ amount in Great leaks and Balady shoots and roots after treatment with different concentration of cadmium as compared to untreated control (Table 6). The induction percent of $\mathrm{H}_{2} \mathrm{O}_{2}$ concentration is approximately the same in both cultivars.

Table 6: $\mathrm{H}_{2} \mathrm{O}_{2}$ levels of roots and shoots in Great leaks and Balady cultivars exposed to different $\mathrm{Cd}$ concentrations.

\begin{tabular}{|c|c|c|c|c|}
\hline \multicolumn{5}{|c|}{ Cadmium concentrations } \\
\hline Plant cultivars & $0 \mu \mathrm{mol}$ & $16 \mu \mathrm{mol}$ & $24 \mu \mathrm{mol}$ & $32 \mu \mathrm{mol}$ \\
\hline \multicolumn{5}{|c|}{ Shoot $\mathrm{H}_{2} \mathrm{O}_{2}$} \\
\hline Great leaks & $20.42 \pm 0.846$ & $23.40 \pm 0.883^{*}$ & $25.81 \pm 0.382^{*}$ & $28.01 \pm 0.878^{*}$ \\
\hline Balady & $23.23 \pm 0.723$ & $26.84 \pm 0.792^{*}$ & $30.31 \pm 0.815^{*}$ & $32.16 \pm 0.774^{*}$ \\
\hline \multicolumn{5}{|c|}{ Root $\mathrm{H}_{2} \mathrm{O}_{2}$} \\
\hline Great leaks & $20.11 \pm 0.619$ & $22.58 \pm 0.847^{\star}$ & $26.28 \pm 0.714^{*}$ & $28.44 \pm 0.429^{*}$ \\
\hline Balady & $20.82 \pm 0.912$ & $24.28 \pm 0.664^{*}$ & $28.79 \pm 0.596^{*}$ & $30.65 \pm 0.603^{*}$ \\
\hline
\end{tabular}

Values are means \pm SEM of three different replicates.

$\mathrm{H}_{2} \mathrm{O}_{2}$, Hydrogen peroxide; nmole/g fresh weight.

${ }^{*}$ Differences were significant at $p<0.05$.

\section{Assessment of antioxidant enzymes activities}

There was a significant increase in activities of antioxidant enzymes (CAT and GST) in Great leaks and Balady roots and shoots exposed to Cd treatment (Table 7 and 8). In general, the induction of these enzymes at different concentration of $\mathrm{Cd}$ was more than untreated control. CAT activity was observed to be increased in Balady shoots and roots more than Great leaks. GST activity showed a concentration dependent response with a gradual increase up to $32 \mu \mathrm{mol}$ Cd however, the increase was more in Balady shoots and roots where the maximum activity (37.5\% higher than control) was noticed in Balady shoots. 
El-Kafafi. E. et al.

Table 7: Catalase (CAT) activity of roots and shoots in Great leaks and Balady cultivars exposed to different $\mathrm{Cd}$ concentrations.

\begin{tabular}{|c|c|c|c|c|}
\hline \multicolumn{5}{c|}{ Cadmium concentrations } \\
\hline Plant cultivars & $\mathbf{0} \boldsymbol{\mu m o l}$ & $\mathbf{1 6} \boldsymbol{\mu m o l}$ & $\mathbf{2 4} \boldsymbol{\mu m o l}$ & $\mathbf{3 2} \boldsymbol{\mu m o l}$ \\
\hline \multicolumn{5}{|c|}{ Shoot CAT } \\
\hline Great leaks & $19.67 \pm 0.463$ & $23.35 \pm 0.615^{*}$ & $25.19 \pm 0.874^{*}$ & $26.93 \pm 0.979^{*}$ \\
\hline Balady & $20.90 \pm 0.73$ & $25.47 \pm 1.00^{*}$ & $28.21 \pm 0.64^{*}$ & $30.05 \pm 0.52^{*}$ \\
\hline \multicolumn{5}{|c|}{ Root CAT } \\
\hline Great leaks & $23.73 \pm 0.670$ & $27.92 \pm 0.504^{*}$ & $29.76 \pm 0.665^{*}$ & $32.74 \pm 1.007^{*}$ \\
\hline Balady & $23.73 \pm 0.670$ & $24.10 \pm 0.988^{*}$ & $26.18 \pm 0.478^{*}$ & $28.77 \pm 0.850^{*}$ \\
\hline
\end{tabular}

Values are means \pm SEM of three different replicates.

CAT, catalase enzyme; CAT, EU/g fresh weight.

*Differences were significant at $p<0.05$.

Table 8: Glutathione S-transferase activity (GST) of roots and shoots in Great leaks and Balady cultivars exposed to different $\mathbf{C d}$ concentrations.

\begin{tabular}{|c|c|c|c|c|}
\hline \multicolumn{5}{|c|}{ Cadmium concentrations } \\
\hline Plant cultivars & $\mathbf{0} \boldsymbol{\mu m o l}$ & $\mathbf{1 6} \boldsymbol{\mu m o l}$ & $\mathbf{2 4} \boldsymbol{\mu m o l}$ & $\mathbf{3 2 \mu m o l}$ \\
\hline \multicolumn{5}{|c|}{ Shoot GST } \\
\hline Great leaks & $21.8 \pm 0.46$ & $24.0 \pm 0.78$ & $25.5 \pm 1.07^{*}$ & $29.0 \pm 1.22^{*}$ \\
\hline Balady & $22.5 \pm 0.45$ & $24.7 \pm 1.00$ & $27.6 \pm 1.61^{*}$ & $31.0 \pm 0.24^{*}$ \\
\hline \multicolumn{5}{|c|}{ Root GST } \\
\hline Great leaks & $24.9 \pm 0.36$ & $27.3 \pm 0.44$ & $28.6 \pm 0.41^{*}$ & $31.5 \pm 1.12^{*}$ \\
\hline Balady & $25.2 \pm 0.43$ & $28.3 \pm 0.24$ & $31.0 \pm 0.91^{*}$ & $34.4 \pm 0.90^{*}$ \\
\hline
\end{tabular}

Values are means \pm SEM of three different replicates.

GST, glutathione S-transferase enzyme; units/ mg protein

*Differences were significant at $p<0.05$.

\section{Assessment of non-protein thiols.}

The concentrations of non-protein thiols (NPT) in the Cd-treated roots or shoots were significantly higher than those of the untreated controls. The maximum level of NPT was observed at $32 \mu \mathrm{mol} \mathrm{Cd}$ as compared with control (Table 9). The concentration of NPT increased significantly in Balady shoot more than Great leaks shoots.

Table 9: Non protein thiols (NPT) concentrations of roots and shoots in Great leaks and Balady cultivars exposed to different $\mathrm{Cd}$ concentrations

\begin{tabular}{|c|c|c|c|c|}
\hline \multicolumn{5}{|c|}{ Cadmium concentrations } \\
\hline Plant cultivars & $\mathbf{0} \boldsymbol{\mu m o l}$ & $\mathbf{1 6} \boldsymbol{\mu m o l}$ & $\mathbf{2 4} \boldsymbol{\mu m o l}$ & $\mathbf{3 2} \boldsymbol{\mu m o l}$ \\
\hline \multicolumn{5}{|c|}{ Shoot NPT } \\
\hline Great leaks & $1.94 \pm 0.040$ & $2.36 \pm 0.043^{*}$ & $2.65 \pm 0.061^{*}$ & $2.75 \pm 0.059$ \\
\hline Balady & $1.98 \pm 0.045$ & $2.46 \pm 0.032^{*}$ & $2.79 \pm 0.056^{\star}$ & $2.94 \pm 0.052^{\star}$ \\
\hline \multicolumn{5}{|c|}{ Root NPT } \\
\hline Great leaks & $3.23 \pm 0.055$ & $3.73 \pm 0.074^{\star}$ & $3.92 \pm 0.023^{*}$ & $4.56 \pm 0.108^{*}$ \\
\hline Balady & $2.54 \pm 0.041$ & $2.99 \pm 0.049^{*}$ & $3.32 \pm 0.055^{\star}$ & $3.84 \pm 0.047^{*}$ \\
\hline
\end{tabular}

Values are means \pm SEM of three different replicates.

NPT, non-protein thiols; nmole/g fresh weight.

*Differences were significant at $p<0.05$. 
Effect of cadmium on the protein profile of two Lactuca sativa cultivars

Figure 1 showes that the number and density of polypeptides gradually decreased as $\mathrm{Cd}$ concentration increased. The results showed that the Balady cultivar was more stable against protein damage at $\mathrm{Cd}$ concentration of 16 and $24 \mu \mathrm{mol}$ than the Great leaks cultivar at the same concentrations of cadmium.

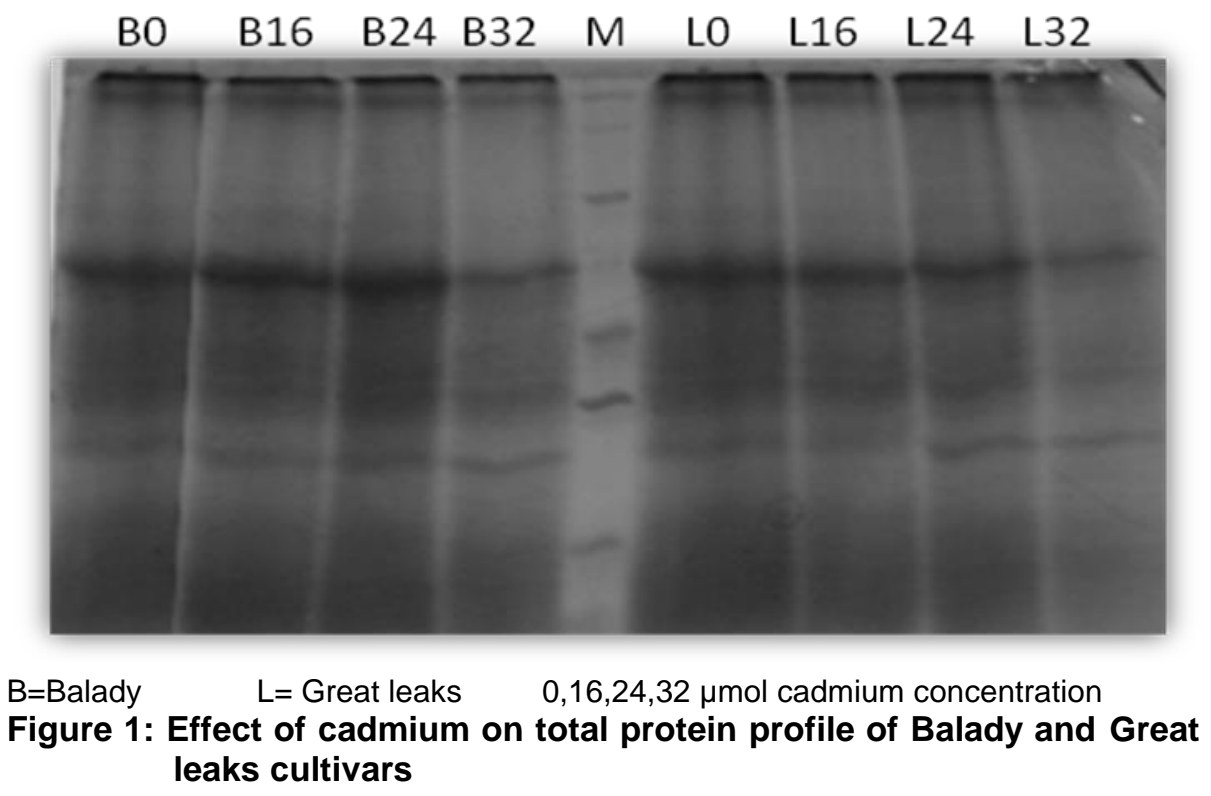

\section{DISCUSSION}

The present results showed differential disposition in both Lactuca sativa and variable decrease as $\mathrm{Cd}$ concentration increased. Data showed that there was a relationship between dry matter decrease and mineral content in Balady and Great leaks. Tolerance indexes of Balady and Great leaks cultivars was changed in the range of $73.44-61.79 \%$ and $70.88-51.08$ $\%$ in response to the concentrations 16 and $32 \mu \mathrm{mol} \mathrm{Cd}$, respectively (Haktanır and Arcak, 1978; Yildiz 2005). In agreement with the present results, Prasad et al. (2004) and Abdel-Latif (2008) reported that high Cd inhibits the formation of chlorophyll by interfering with protochlorophyllide production.

The Cd uptake and accumulation in roots and shoots of both Lactuca cultivars were varied. The Cd content in roots and shoots were increased as $\mathrm{Cd}$ concentration increased. Cadmium ions were mainly accumulated in the roots, but small amounts of $\mathrm{Cd}$ were transferred to the shoots. It was observed that Balady shoots had less uptake of $\mathrm{Cd}$ than Great leaks cultivar (Lagriffoul et al., 1998). These differences in root and shoot uptake might be explained by the fact that one of the normal functions of roots is to selectively acquire ions from soil solution, whereas shoot tissue does not normally play this role (Salt et al., 1997). The accumulation of Cd decreased from 
epidermis to inner parts of the root cortex. As the endodermis constitutes a barrier to ion transport, root cortex cells usually contain higher element concentrations than cells in the central vascular cylinder (Hagemeyer and Breckle, 1996). The induction in gene expression and activities of an antioxidant enzyme and non protein thiol confer Balady cultivar some measure of $\mathrm{Cd}$ tolerance in addition to the presence of strong Cd-binding proteins in the roots.

The effects of $\mathrm{Cd}$ on $\mathrm{Ca}, \mathrm{Fe}, \mathrm{Mn}$ and $\mathrm{Zn}$ concentration in both Lactuca sativa cultivars varied with the concentrations of $\mathrm{Cd}$ added. $\mathrm{Ca}, \mathrm{Fe}, \mathrm{Mn}$ and $\mathrm{Zn}$ uptake accumulation significantly decreased with increasing $\mathrm{Cd}$ ions in nutrient solution in both shoot and root tissues as compared to control plants (Table 3, 4), but the positive effect on Fe concentration was observed in the roots of Balady cultivar. In agreement with our results, Hernández et al., (1998) found that $\mathrm{Fe}$ in pea plants treated with $50 \mu \mathrm{M} \mathrm{Cd}$ was higher than that recorded in the control ones.

The present study indicates that $\mathrm{Cd}$ exposure for different concentrations resulted in oxidative stress measured in terms of MDA content and $\mathrm{H}_{2} \mathrm{O}_{2}$ generation. MDA, a major TBARS, is an indicator of lipid peroxidation (Apel and Hirt, 2004) and links to peroxidation of polyunsaturated fatty acids in the membranes thereby releasing free radicals (Mustafa, 1990). The concentration of MDA was observed to be increased in Great leaks shoots than Balady roots. The same trend was observed in Great leaks roots that indicate that $\mathrm{Cd}$ absorption in Great leaks roots is more than Balady roots. This is can be explained by the increase in $\mathrm{Cd}$ accumulation in Great leaks shoots and roots. Also, Cd-induced lipid peroxidation has been reported in several plant species including pea (Sandalio et al., 2001), sunflower (Gallego et al., 1996), rice (Hsu and Kao, 2004), Tagetes erecta (Uraguchi et al., 2006) and wheat (Singh et al., 2008). In agreement with the present study, increased MDA content in response to Cd exposure is one of the mechanisms of Cd-toxicity (Dixit et al., 2001; Smeets et al., 2005; Garnier et al., 2006; Rodrıguez-Serrano et al., 2006; Chen et al, 2010). Cd-induced enhanced lipid peroxidation and altered electrolyte leakage suggests a negative impact on membrane integrity and thus membrane deterioration. $\mathrm{Cd}$ reportedly affects normal ion exchange capacity of plasma membrane and all the physiological activities linked to membrane functioning (Hernandez and Coke, 1997).

Furthermore, in the present study, Cd increased $\mathrm{H}_{2} \mathrm{O}_{2}$ content in both Great leaks and Balady shoots and roots as compared with control. It is similar to earlier reports indicating increased $\mathrm{H}_{2} \mathrm{O}_{2}$ content in response to $\mathrm{Cd}$ treatment under laboratory condition (Schutzendubel et al., 2001; RomeroPuertas et al., 2004; Rodriguez-Serrano et al., 2006). The observed changes in the contents of oxidative markers (MDA and $\mathrm{H}_{2} \mathrm{O}_{2}$ ) following $\mathrm{Cd}$ exposure indicates that $\mathrm{Cd}$-induced oxidative stress in the Great leaks and Balady cultivars shoots and roots. The increase in $\mathrm{H}_{2} \mathrm{O}_{2}$ in response to $\mathrm{Cd}$ has also been reported in roots of bread wheat and it was correlated to oxidative stress in roots (Ranieri et al., 2005). Increased levels of MDA and $\mathrm{H}_{2} \mathrm{O}_{2}$ indicated that $\mathrm{Cd}$ exposure results in generation of ROS, which are highly toxic molecules and cause cellular damage in plants (Apel and Hirt, 2004). 
However, unlike other heavy metals, Cd being a non-redox metal, does not act through Haber-Weiss/Fenton reaction (Salin, 1988). It is parallel to a study by Garnier et al. (2006) who reported that Cd exposure to tobacco cells results in rapid $\mathrm{O}_{2}$-generation that lead to oxidative damage.

An upregulation of scavenging enzymes CAT and GST to counter Cdinduced stress in Great leaks and Balady cultivars shoots and roots was observed. The observed enhancement in activities of CAT and GST in response to $\mathrm{Cd}$ exposure is in agreement with other reports (Dixit et al., 2001; Schutzendubel et al., 2001; Olmos et al., 2003; Smeets et al., 2005; Rodriguez-Serrano et al., 2006, Li et al., 2011). The activity of CAT and GST enzymes (Tables 7-8) involved in GSH metabolism showed differential responses upon $\mathrm{Cd}$ exposure. The activity of CAT and GST showed a concentration dependent response with a gradual increase up to $32 \mu \mathrm{mol} \mathrm{Cd}$ treatment. GSTs catalyze GSH dependent detoxification of peroxides and xenobiotics and presumably heavy metals too (Moons, 2003). The observed induction in GST activity suggests its involvement in detoxification of $\mathrm{Cd}$ (Mishra et al., 2008). Induction of various isoforms of GSTs in response to Cd has been reported in rice roots (Moons, 2003) and soyabean cells (Sobkoviak and Deckert, 2006).

Cellular non-protein thiol (NPT) increased significantly in shoots and roots of $\mathrm{Cd}$-treated cultivars indicated their crucial role in ROS scavenging. NPT is an important antioxidant molecule for Cd detoxification by forming $\mathrm{Cd}$ bindings with their high affinity for $\mathrm{SH}$ groups (Pietrini et al., 2003). In agreement with the present study, Mishra et al. (2009) observed a significantly high increase in the levels of thiols in response to $\mathrm{Cd}$ concentration. The maximum level of NP-SH was observed at $32 \mu \mathrm{mol} \mathrm{Cd}$ treatment, which was about 1.5-fold higher than control in both Great leaks and Balady cultivars shoots and roots (Table 9 ).

In conclusion, variation of total chlorophyll, tolerance indexes, cadmium accumulation, differential expression and antioxidant enzyme activities induced by $\mathrm{Cd}$ treatments revealed that Balady cultivar was more tolerant to $\mathrm{Cd}$ stress compared with Great leaks. Cd stress resulted in a reduction in photosynthetic efficiency and most nutrient uptake. The data indicated that there are co-ordination of gene expression, regulation ion transport process operating in different root layer more efficient in Balady cultivar compared with Great leaks, some protective mechanisms, such as activity of antioxidant enzymes may be protected from oxidative damage. In the case of Great leaks, Cd treatments possibly caused more oxidative and total protein profile damage than they did to Balady cultivar.

Analysis and evaluation of all parameters allowed classification of cultivars as tolerant (Balady) and less tolerant (Great leaks). Research must be expanded to prevent the risk of $\mathrm{Cd}$ uptake by crops in the food chain before the growth of Great leaks in Cd polluted regions. 


\section{REFERENCES}

Abdel-Latif ,A., 2008. Cadmium induced changes in pigment content, ion uptake, proline content and phosphoenolpyruvate carboxylase activity in Triticum Aestivum seedlings. Australian. J. Basic Appl. Sci., 2, 57-62

Apel, K. and Hirt, H., 2004. Reactive oxygen species: metabolism, oxidative stress, and signal transduction. Ann. Rev. Plant Biol. 55, 373- 399.

Cakmak, I. and Marschner, H., 1992. Magnesium deficiency and high light intensity enhance activities of superoxide dismutase, ascorbate peroxidase and glutathione reductase in bean leaves. Plant Physiol. 98, 1222-1227.

Chen, F., Wang, F., Wu, F., Mao, W., Zhang, G.and Zhou, M. (2010). Modulation of exogenous glutathione in antioxidant defense system against $\mathrm{Cd}$ stress in the two barley cultivars differing in Cd tolerance. Plant Physiol. Biochem. 48: 663- 672 .

Clemens, S., 2006. Toxic metal accumulation, responses to exposure and mechanisms of tolerance in plants. Biochimie 88, 1707-1719.

Das, P., S. Samantaray and G.R. Rout. 1997. Studies on cadmium toxicity in plants: a review. Environ. Pollu., 98: 29-36.

Das, P., S. Samantaray and G.R. Rout. (1999). Studies on Cd toxicity in plants: A review. India.

Dixit V, Pandey V. and Syam R. 2001. Different antioxidative responses to cadmium in roots and leaves of pea (Pisum sativum L., cv. Azad). J. Exp. Bot., 52: 1101-9.

Fuhrer, J., 1982. Ethylene biosynthesis and cadmium toxicity in leaf tissue of beans Phaseolus vulgaris L. Plant Physiol., 70, 162-167

Gallego, S.M., Benavides, M.P. and Tomaro, M.L., 1996. Effect of heavy metal ion excess on sunflower leaves: evidence for involvement of oxidative stress. Plant Sci. 121, 151-159.

Garnier, L., Francoise, S.-P., Thuleau, P., Agnel, J.-P., Blein, J.-P., Ranjeva, R. and Montillet, J.-L., 2006. Cadmium affects tobacco cells by a series of three waves of reactive oxygen species that contribute to cytotoxicity. Plant Cell Environ. 29, 1956-1969.

Habig, W.H. and Jacoby, W.B., 1981. Assay for differentiation of glutathione Stransferases. Meth. Enzymol. 77, 398-405.

Hagemeyer, J. and S.W. Breckle. 1996. Growth under trace element stress. In: Plant Roots. pp. 415-431. (Eds.): Y. Waisel, A. Eshel and U. Kafkafi. The hidden half. Marcel Dekker, Inc, New York, Basel, Hongkong.

Haktanır, K. and S. Arcak. 1978. Çevre Kirliliği. Ankara Üniversitesi. Ziraat Fakültesi, yay no:1503. Ders Kitabı: 457, Ankara.

Heath RL, and Packer L.1968. Photoperoxidation in isolated chloroplast. I. Kinetics and stoichiometry of fatty acid peroxidation. Arch Biochem Biophys; 25:189-98.

Hernandez, L.E. and Coke, D.T., 1997. Modification of the root plasma membrane lipid composition of cadmium-treated Pisum sativum. J. Exp. Bot. 48, 13751381. 
Hernández, L.E., E. Lozano-Rodríguez, A. Gárate and R. Carpena-Ruiz. 1998. Influence of cadmium on the uptake, tissue accumulation and subcellular distribution of manganese in pea seedlings. Plant Sci., 132: 139-151.

Hipkins, M.F. and N.R. Baker. (1986). Photosynthesis energy transduction. p. 51105. In: M.F. Hipkins and N.R. Baker (eds.), Spectroscopy. IRL, Oxford, UK.

Hsu, Y.T., and Kao, C.H., 2004. Cadmium toxicity is reduced by nitric oxide in rice leaves. Plant Growth Regul. 42, 227-238.

Lagriffoul, A., B. Mocquot, M. Mench and J. Vangronsveld. 1998. Cadmium toxicity effects on growth, mineral and chlorophyll contents, and activities of stress related enzymes in young maize plants (Zea mays L.). Plant Soil, 200: 241250.

Lee, K.G., B.A. Cunningham, G.M. Paulsen, G.H. Liang and R.B. Moore. 1976. Effect of cadmium on respiration rate and activity of several enzymes in soybean seedlings. Physiol. Plant., 36: 4-6.

Li, Q., Yu, B., Gao, Y., Dai, A. and Bai, J. (2011) Cinnamic acid pretreatment mitigates chilling stress of cucumber leaves through altering antioxidant enzyme activity J. Plant Physiol. 168: 927-934.

Liu, D.H. and I. Kottke. 2003. Subcellular localization of $\mathrm{Cd}$ in the root cells of Allium sativum by electron energy loss spectroscopy. J. Biosci., 28(4): 471478.

Lowry, O.H., Rosenbrough, N.J., Farr, A.L. and Randal, R.J., 1951. Protein measurement with the folin phenol reagent. J. Biol. Chem. 193, 265-275.

Metwally A, Finkemeier I, Georgi M and Dietz KJ., 2003.Salicylic acid alleviates the cadmium toxicity in barley seedlings. Plant Physiol. 132:272-81.

Miller, R.J., J.E. Bittell and D.E. Koeppe. 1973. The effect of cadmium on electron and energy transfer reactions in corn mitochondria. Biol. Plant., 28: 166171.

Mishra, S., Srivastava, S., Tripathi, R.D., Dwivedi, S and Shukla, M.K., 2008. Response of antioxidant enzymes in coontail (Ceratophyllum demersum L.) plants under cadmium stress. Environ. Toxicol. 23, 294-301.

Mishra, S., Tripathi R.D., Srivastava, S., Dwivedi, S., Trivedi , P.K., Dhankher , O.P and Khare, A., 2009. Thiol metabolism play significant role during cadmium detoxification by Ceratophyllum demersum L. Bioresource Technology 100, 2155-2161

Moons, A., 2003. Osgstu3 and Osgstu4, encoding tau class glutathione Stransferases, are heavy metal- and hypoxic stress-induced and differentially salt stress-responsive in rice roots. FEBS Lett. 553, 427-432.

Mustafa, M.G., 1990. Biochemical basis of ozone toxicity. Free Radic. Biol. Med. 9, 245-265. Marschner H. (1995): Mineral nutrition of higher plants. 2nd ed. Acad. Press, London.

Olmos, E., Martinez-Solano, J.R., Piqueras, A. and Hellin, E., 2003. Early steps in the oxidative burst induced by cadmium in cultured tobacco cells (BY-2 line). J. Exp. Bot. 54, 291-301.

Page, A. L., R. H. Miller and D. R. Keeny (1982). Methods of soil analysis. Part $n$. Chemical and microbiological properties ( $2^{\text {nd }}$ ed.) Amer. Soc. Agron. Monograph no. 9 Madison, Wisconsin, USA. 
Pietrini F, lannelli MA, Pasqualini S and Massacci A. 2003. Interaction of cadmium with glutathione and photosynthesis in developing leaves and chloroplasts of Phragmites australis (Cav.) Trin. ex Steudel. Plant Physiol; 133:829-37.

Prasad, S., R. Dwivedi, M. Zeeshan and R. Singh, 2004. UV-B and cadmium induced changes in pigments, photosynthetic electron transport activity, antioxidant levels and antioxidative enzyme activities of Riccia sp. Acta Physiol. Plant., 26: 423-430.

Ranieri A, Castagna A, Scebba F, Careri M, Zagnoni I, Predieri G, et al. Oxidative stress and phytochelatin characterisation in bread wheat exposed to cadmium excess. Plant Physiol Biochem 2005; 43: 45-54.

Rodrıguez-Serrano, M., Romero-Puertas, M.C., Zabalza, A., Corpas, F.J., G'omez, M., del R'ıo, L.A., Sandalio, L.M., 2006. Cadmium effect on oxidative metabolism of pea (Pisum sativum L.) roots. Imaging of reactive oxygen species and nitric oxide accumulation in vivo. Plant Cell Environ. 29, 1532-1544.

Romero-Puertas, M.C., Rodriguez-Serrano, M., Corpas, F.J., Gomez, M., del Rio, L.A., Sandalio, L.M., 2004. Cadmium-induced subcellular accumulation of $\mathrm{O}_{2}$ and $\mathrm{H}_{2} \mathrm{O}_{2}$ in pea leaves. Plant Cell Environ. 27, 1122-1134.

Rosas, I., M.E. Carbajal, S. Gomez-arroyo, R. Belmont and R.Villalogos-Pietrini. 1984.Cytogenetic effects on cadmium accumulation on water hyacinth (Eichornia crassipes). Environ. Pollut., 33: 386-395.

Salin ML. Toxic oxygen species and protective systems of the chloroplasts. Physiol Plant 1988;72:681-9.

Salt, D.E., I.J. Pickering, R.C. Prince, D. Gleba, S. Dushenkov, R.D. Smith and I. Raskin 1997. Metal accumulation by aquacultured seedlings of Indian mustard. Environ. Sci. Tech., 31: 1636-1644.

Sandalio, L.M., Dalurzo, H.C., G'omez, M., Romero-Puertas, M.C., del R'ıo, L.A., 2001. Cadmium-induced changes in the growth and oxidative metabolism of pea plants. J. Exp. Bot. 52, 2115-2126.

Sanità di Toppi. L and R. Gabbrielli 1999. Response to cadmium in higher plants. Environ. Exp.Bot., 41: 105-130.

Schutzendubel, A. Schwanz, P. Teichmann, T. Gross, K. Langenfeld-Heyser, R. Godbold, D.L. Polle, A. 2001. Cadmium induced changes in antioxidative systems, hydrogen peroxide content, and differentiation in scots pine roots. Plant Physiol. 127, 887-898.

Schutzendubel, A., P. Nikolova, C. Rudolf and A. Polle. 2002. Cadmium and $\mathrm{H}_{2} \mathrm{O}_{2}$ induced oxidative stress in populus $\mathrm{x}$ canescens roots. Plant Physiol. Biochem., 40: 577-584.

Singh, H. P. Batish, D. R. Kaur, G. Arora, K. and Kohli, R. K. 2008, Nitric oxide (as sodium nitroprusside) supplementation ameliorates $\mathrm{Cd}$ toxicity in hydroponically grown wheat roots. Environmental and Experimental Botany 63: 158-167

Smeets, K., Cuypers, A., Lambrechts, A., Semane, B., Hoet, P., Van Laere, A. and Vangronsveld, J., 2005. Induction of oxidative stress and antioxidative mechanisms in Phaseolus vulgaris after Cd application. Plant Physiol. Biochem. 43, 437-444.

Sobkoviak, R. and Deckert, J., 2006. Proteins induced by cadmium in soyabean cells. J. Plant Physiol. 163, 1203-1206. 
Uraguchi, S., Watanabe, I., Yoshitomi, A., Kiyono, M. and Kuno, K., 2006. Characteristics of cadmium accumulation and tolerance in novel $\mathrm{Cd}$ accumulating crops, Avena strigosa and Crotalaria juncea. J. Exp. Bot. 57, 2955-2965.

Velikova, V., Yordanov, I. and Edreva, A., 2000. Oxidative stress and some antioxidant systems in acid rain-treated bean plants. Plant Sci. 151, 59-66.

Wagner, G.J., 1993. Accumulation of cadmium in crop plants and its consequences to human health. Adv. Agron. 51, 173-212.

Waisberg, M., Joseph, P., Hale, B., Bayersmann, D., 2003. Molecular and cellular mechanisms of cadmium carcinogenesis. Toxicology 192, 95-117.

Yildiz, N., 2005. Response of tomato and corn plants to increasing $\mathrm{Cd}$ levels in nutrient culture. Pak. J. Bot., 37(3): 593—599.

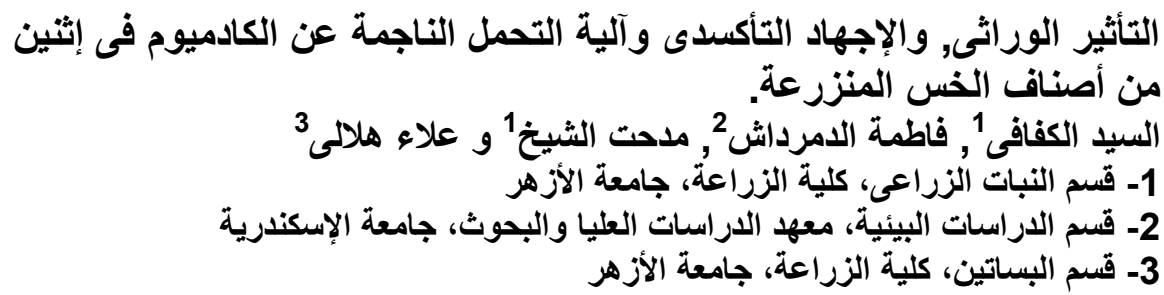

أجريت هذه التجربة فى المزارع المائية لدراسة تأثير الكادميوم على الإجهاد التأكسدى، والتعبير

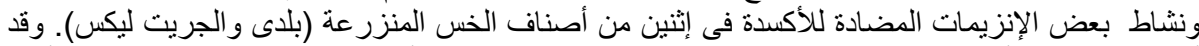

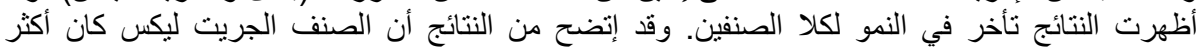

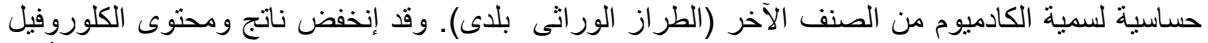

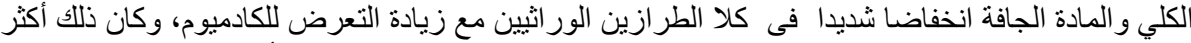

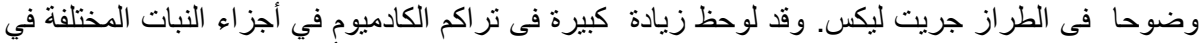

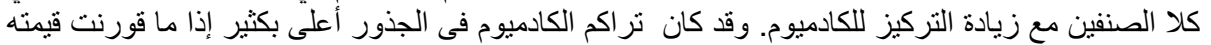

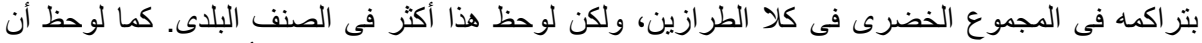

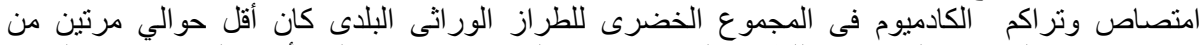

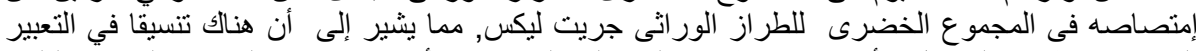

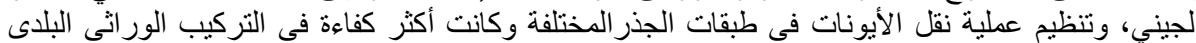

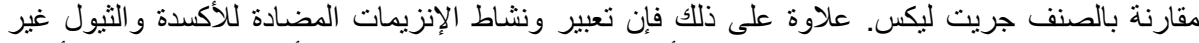

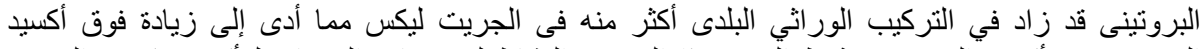

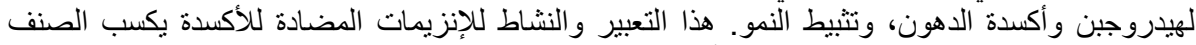

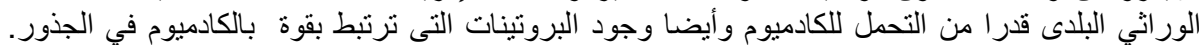

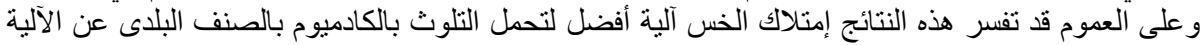
الموجودة بالصنف الجريت ليكس.

\footnotetext{
كلية الزراعة - جامعة المنصورة كلية زراعة دمياط - جامعة المنصورة
}

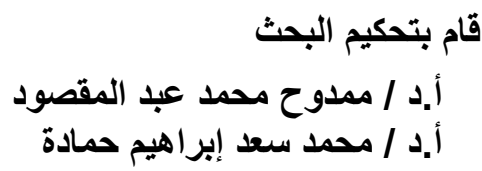

